\title{
The cholesterol-lowering effects of oat varieties based on their difference in the composition of proteins and lipids
}

Lina Guo ${ }^{1 \dagger}$, Li-Tao Tong ${ }^{1 \dagger}$, Liya Liu' ${ }^{1}$, Kui Zhong ${ }^{1}$, Ju Qiu ${ }^{2}$ and Sumei Zhou ${ }^{1 *}$

\begin{abstract}
Background: The aim of present study is to investigate the hypocholesterolemic effects of the oat components other than the $\beta$-glucan in rats fed with a hypercholesterolemic diet.

Methods: Four-week-old male Wister rats were divided into 6 groups of 7 rats each with similar mean body weights and serum cholesterol concentrations. Rats were fed with the experimental diets containing $10 \%$ oats flour for 30 days. Food intake was recorded and monitored everyday to ensure the similar contents of protein, starch, lipid and cellulose in all groups. The lipids levels in serum, liver, and faeces were determined.

Results: The plasma total cholesterol concentrations in different oat groups were significantly reduced compared with the control group, and the effects were different among oat groups. The decrease extent of plasma total cholesterol and low-density lipoprotein-cholesterol concentrations increased with the increase of the proteins and lipids contents. Moreover, liver total cholesterol and cholesterol ester contents were markedly decreased. The fecal bile acids concentrations in the oat groups were significantly increased. Oat proteins had lower Lysine/Arginin (0.59 0.66) and Methionin/Glycine (0.27 0.35) ratio than casein (Lysine/Arginin, 2.33; Methionin/Glycine, 1.51). Oat lipids contained higher contents of total Vitamin E and plant sterols than that in soybean oil.

Conclusion: These results indicated that dietary oat improved hypercholesterolemia by increasing the excretions of fecal bile acids, and this improvement was not only related to $\beta$-glucan, but also attributed to the lipids and proteins. Oat proteins decreased serum total cholesterol and low-density lipoprotein-cholesterol contents due to their low Lysine/Arginin and Methionin/Glycine ratio. The co-existence of oleic acid, linoleic, vitamin E, or plant sterols accounted for the hypocholesterolemic properties of oat lipids.
\end{abstract}

Keywords: Oat hypocholesterolemic effect proteins lipids

\section{Introduction}

It is well known that dietary oat have been reported to reduce serum cholesterol [1] and obesity [2], prevent coronary heart disease [3], and improve symptoms of diabetes [4]. Numerous studies indicate that oat have high contents of $\beta$-glucan which is beneficial to human health, as it is considered to be responsible for these health benefits [5-7]. Oat contains $2.0 \sim 7.5 \% \beta$-glucan [8], $13 \sim 20 \%$ protein [9], $2 \sim 12 \%$ crude fat [10], and about $60 \%$ starch [11].

\footnotetext{
* Correspondence: sumeizhoucaas@gmail.com

${ }^{\dagger}$ Equal contributors

'Institute of Agro-Products Processing Science and Technology, Chinese Academy of Agricultural Sciences/Key Laboratory of Agro-Products Processing, Ministry of Agriculture, 100193 Beijing, China

Full list of author information is available at the end of the article
}

Most of the studies focus on the health benefits of $\beta$ glucan, while the effects of other main components on reducing serum cholesterol are still unknown.

Numerous studies indicate that dietary plant proteins, such as soybean [12,13], rice $[14,15]$ and buckwheat [16], reduce effectively serum cholesterol levels and prevent cardiovascular diseases. Compared with other cereals, oat contains higher content of protein, and the composition of oat amino acid is more reasonable [7]. Moreover, the levels of crude fat, showing the nutritional and functional potential [17], in oat are much higher than that of other cereal grain, which leads oat to become an excellent source of functional food [18]. Oat lipids are rich in polyunsaturated fatty acids, Vitamin $\mathrm{E}$ 
[7] and plan sterols [19]. Judd and Truswell concluded that both the lipophilic and lipophobic components of oat played a major role in decreasing serum cholesterol in humans [20]. However, there is no information about the effect of these components other than $\beta$-glucan in oat on the reduction of serum cholesterol in animals or humans.

In the present study, we determined the nutrient contents of different oat varieties, and selected five varieties. The five oat varieties have different contents of proteins and lipids, but the contents of $\beta$-glucan are similar, to investigate the cholesterol-lowing effects of the components other than $\beta$-glucan in Wistar-Lewis rats fed a hypercholesterolemic diet.

\section{Materials and methods Materials}

Twenty-eight oat varieties, including huazao-No.2(hebei), Jinyan-No.8(shanxi), Jinyan-No.9(shanxi), pinyin-No.1(shanxi), baiyan-No.2(shanxi), bayou-No.8(shanxi), jinyan-No.13(youyu), bayou-No.8(youyu), yanke-No.1(neimenggu), caoyou-No.1 (neimenggu), neiyan-No5(neimenggu), dingyou-No.1(gansu), dingyou-No.2(gansu), dingyou-No.3(gansu), dingyou-No.4 (gansu), dingyou-No.5(gansu), dingyou-No.6(gansu), dingyouNo.7(gansu), dingyou-No.8(gansu), baiyan-No.4(jilin), baiyanNo.5(jilin), baiyan-No.8(jilin), bayan-No.2(sichuan), bayan-No.2 (xinjiang), huawan-No.6(xinjiang), ningyou-No.1(ningxia), yanke-No1(ningxia), and baiyan-No.2(ningxia), were collected from main regions of oat cultivation in China between October and November, 2011. Oats were crushed into flour and then stored at $4^{\circ} \mathrm{C}$ for further study.

\section{Components determination}

The contents of oat protein, lipid, $\beta$-glucan, ash and starch were determined based on GB/T5511-2008, GB/T147722008, AOAC995.16, GB/T 22510-2008 and AOAC 996.11, respectively. Amino acid compositions of oat proteins and casein were determined using an amino acid autoanalyzer (L-8900-type amino acid analyzer, Hitachi, Ltd., Japan) based on GB/T5009124-2003. Fatty acid compositions of oat lipids and soybean oil were determined by gas-liquid chromatography based on ISO 5508-1990. The Vitamin E content of oil was determined by high-performance liquid chromatography (HPLC) equipped with ultraviolet detector according to NY/T 1598-2008, C18 $5 \mu \mathrm{m}, 4.6 \times 250 \mathrm{~mm}$ column was used. The sterol content of oil was determined by the method of UNI EN ISO 12228 (1999). The sterols were derivatized to trimethylsilyl ethers and its quantification by gas-liquid chromatography with a CP-Sil $5 \mathrm{CB}$ capillary column was performed as follow: the column temperature was from $100^{\circ} \mathrm{C}$ to $235^{\circ} \mathrm{C}\left(10^{\circ} \mathrm{C} / \mathrm{min}\right) ; 0.5 \mathrm{~min}$ isotherm; the column temperature was from $235^{\circ} \mathrm{C}$ to $300^{\circ} \mathrm{C}$ $\left(10^{\circ} \mathrm{C} / \mathrm{min}\right) ; 3 \mathrm{~min}$ isotherm; injector $300^{\circ} \mathrm{C}$; flame ionization detector $320^{\circ} \mathrm{C}$. Results mentioned above were on dry weight basis.

\section{Animals and diets}

Four-week-old male Wister rats were purchased from Vital River Lab Animal Technology Co, Ltd. (Beijing, China). All animals were housed in cages in an air-conditioned room (temperature, $21-23^{\circ} \mathrm{C}$; humidity, 55-65\%; lights on, 08:0020:00 h). After 7 days of acclimation, rats were divided into 6 groups of 7 rats each with similar mean body weights and

Table 1 Composition of the experimental diets (g/1000 g diet)

\begin{tabular}{|c|c|c|c|c|c|c|}
\hline & Control & Jinyan-No.13 & Bayou-No.8 & Baiyan-No.2 & Dingyou-No.8 & Baiyan-No.8 \\
\hline Casein & 200 & 182.70 & 181.06 & 180.6 & 180.6 & 180.0 \\
\hline Corn starch & 397 & 328.9 & 330.8 & 331.6 & 332.2 & 333.3 \\
\hline Soybean oil & 70 & 64.2 & 63.9 & 63.8 & 62.9 & 62.0 \\
\hline Cellulose & 50 & 43.1 & 43.0 & 43.2 & 43.2 & 43.6 \\
\hline Sucrose & 38.5 & 38.5 & 38.5 & 38.5 & 38.5 & 38.5 \\
\hline L-Cystine & 3 & 3 & 3 & 3 & 3 & 3 \\
\hline Maltodextrin 10 & 132 & 132 & 132 & 132 & 132 & 132 \\
\hline t-Butylhydroquinone & 0.014 & 0.014 & 0.014 & 0.014 & 0.014 & 0.014 \\
\hline Mineral mix & 35 & 35 & 35 & 35 & 35 & 35 \\
\hline Vitamin mix & 10 & 10 & 10 & 10 & 10 & 10 \\
\hline Choline bitartrate & 2.5 & 2.5 & 2.5 & 2.5 & 2.5 & 2.5 \\
\hline Cholesterol & 10 & 10 & 10 & 10 & 10 & 10 \\
\hline Lard & 50 & 50 & 50 & 50 & 50 & 50 \\
\hline Cholate & 2 & 2 & 2 & 2 & 2 & 2 \\
\hline Oat & 0 & 100 & 100 & 100 & 100 & 100 \\
\hline Total & 1000 & 1000 & 1000 & 1000 & 1000 & 1000 \\
\hline
\end{tabular}

Diets were prepared based on AIN-93G recommendations. 


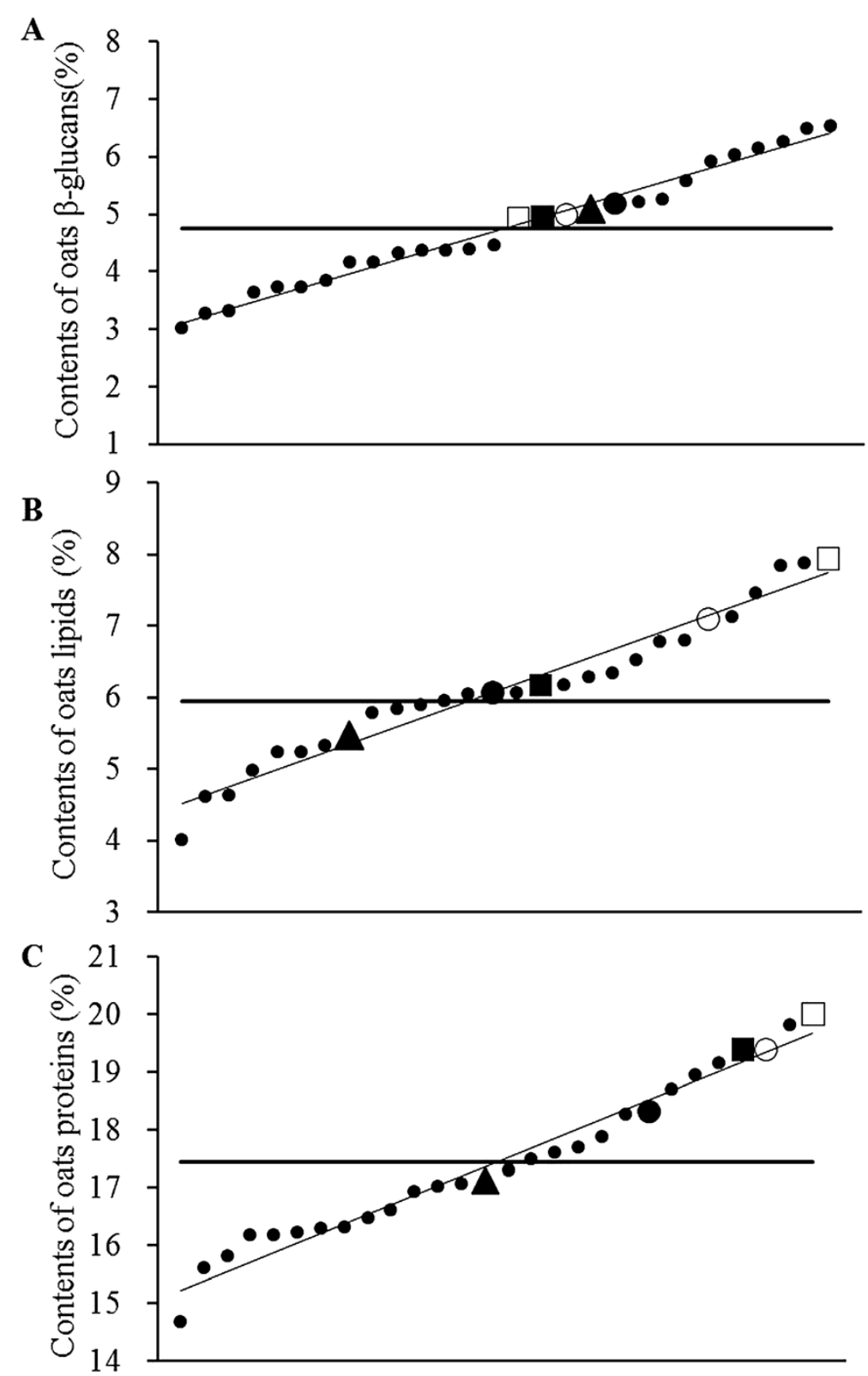

Figure 1 The contents of $\beta$-glucan (A), lipids (B) and proteins (C) in twenty-eight oat varieties. -represent the mean of $\beta$-glucan, lipid and protein contents. $\square$ Baiyan-No.8, O Dingyou-No.8, Baiyan-No.2, Bayou-No.8, $\mathbf{\Delta}$ Jinyan-No.13, $\bullet$ other twenty-three oat varieties.

Table 2 Analysis of oats composition (\%)

\begin{tabular}{lccccr}
\hline Groups & B-glucan & Proteins & Lipids & Starch & Ash \\
\hline Jinyan-No.13 & $5.10 \pm 0.11$ & $17.30 \pm 0.11$ & $5.79 \pm 0.11$ & $58.37 \pm 0.12$ & $1.94 \pm 0.05$ \\
Bayou-No.8 & $5.15 \pm 0.07$ & $18.94 \pm 0.20$ & $6.07 \pm 0.36$ & $56.86 \pm 0.09$ & $1.89 \pm 0.09$ \\
Baiyan-No.2 & $4.99 \pm 0.09$ & $19.37 \pm 0.03$ & $6.17 \pm 0.09$ & $63.12 \pm 0.13$ & $2.29 \pm 0.07$ \\
Dingyou-No.8 & $5.05 \pm 0.12$ & $19.39 \pm 0.14$ & $7.10 \pm 0.67$ & $53.01 \pm 0.11$ & $1.92 \pm 0.09$ \\
Baiyan-No.8 & $4.92 \pm 0.10$ & $19.99 \pm 0.04$ & $7.94 \pm 0.56$ & $55.31 \pm 0.17$ & $1.90 \pm 0.12$ \\
\hline
\end{tabular}

Data are means $\pm S D(n=3)$. 
Table 3 Amino acid composition of dietary proteins ( $\mathrm{mg} / \mathrm{g}$ proteins)

\begin{tabular}{|c|c|c|c|c|c|c|}
\hline Amino acid & Casein & Jinyan-No.13 & Bayou-No.8 & Baiyan-No.2 & Dingyou-No.8 & Baiyan-No.8 \\
\hline Asparagine & 71.3 & 82.6 & 78 & 123.3 & 83.5 & 59.9 \\
\hline Threonine & 40.5 & 33.9 & 32.5 & 52.9 & 34.2 & 25.0 \\
\hline Serine & 50.4 & 47.4 & 44.9 & 74.8 & 46.5 & 34.8 \\
\hline Glutamine & 244.7 & 253.7 & 246.5 & 392.7 & 261.0 & 192.8 \\
\hline Glycine & 18.4 & 50.0 & 48.7 & 80.2 & 50.3 & 37.2 \\
\hline Alanine & 31.6 & 48.9 & 46.1 & 76.5 & 48.7 & 35.6 \\
\hline Cystine & 16.5 & 39.2 & 35.9 & 58.6 & 36.3 & 27.6 \\
\hline Valine & 60.3 & 56.8 & 55.6 & 88.2 & 57.3 & 42.9 \\
\hline Methionine & 27.7 & 14.7 & 15.9 & 22.0 & 16.7 & 12.9 \\
\hline Isoleucine & 50.3 & 38.9 & 39 & 61.0 & 40.8 & 29.8 \\
\hline Leucine & 96.1 & 77.6 & 76.4 & 124.1 & 80.0 & 60.4 \\
\hline Tyrosine & 52.7 & 39.7 & 43.1 & 69.3 & 41.3 & 36.7 \\
\hline Lysine & 77.9 & 59.5 & 57.7 & 96.3 & 58.3 & 45.8 \\
\hline Histidine & 26.2 & 41.4 & 38.9 & 64.3 & 40.9 & 30.3 \\
\hline Arginine & 33.5 & 30.3 & 29.7 & 47.3 & 30.5 & 22.8 \\
\hline Phenylalanine & 48.7 & 62.6 & 66.3 & 104.8 & 68.6 & 51.2 \\
\hline Proline & 104.1 & 48.4 & 48.9 & 85.0 & 52.2 & 38.6 \\
\hline Lysine/arginin & 2.33 & 0.66 & 0.59 & 0.61 & 0.60 & 0.59 \\
\hline Methionin/glycine & 1.51 & 0.29 & 0.33 & 0.27 & 0.33 & 0.35 \\
\hline
\end{tabular}

serum cholesterol concentrations. Rats were fed with the experimental diets for 30 days. The compositions of experimental diets were prepared according to AIN-93G (American Institute of Nutrition 1993) with some modifications (Table 1$)$. Oats (10\% of diet) were added in the experimental diet. Food intake was recorded and monitored everyday to ensure the similar contents of protein, starch, lipid and cellulose in all groups. Body weights were recorded every three days. The rats were fasted for $16 \mathrm{~h}$ and then sacrificed by the removal of the whole blood from the abdominal aorta.

All experiments were carried out according to the P.R. China legislation regarding the use and care of laboratory animals and were approved by the Bioethics Committee of the

Table 4 Fatty acid composition of experimental oats (\%)

\begin{tabular}{lcccccc}
\hline & C16:0 & C18:0 & C18:1 & C18:2 & C18:3 & $\begin{array}{c}\text { Unsaturated } \\
\text { fatty acids }\end{array}$ \\
\hline Jinyan-No.13 & 18.0 & 1.1 & 29.1 & 47.3 & 2.0 & 78.4 \\
Bayou-No.8 & 19.3 & 1.6 & 34.3 & 40.5 & 1.5 & 76.3 \\
Baiyan-No.2 & 18.6 & 1.4 & 31.2 & 43.5 & 1.5 & 76.2 \\
Dingyou-No.8 & 15.5 & 1.6 & 35.8 & 43.8 & 1.4 & 81.0 \\
Baiyan-No.8 & 16.6 & 1.8 & 39.2 & 37.7 & 1.5 & 78.4 \\
Control & 8.5 & 3.4 & 26.5 & 52.8 & 6.7 & 86.0 \\
\hline
\end{tabular}

Unsaturated fatty acids were the sum of C18:1, C18:2 and C18:3.
Institute of Medicinal Plant Development, Chinese Academy of Medical Sciences and Peking Union Medical College.

\section{Analysis of metabolic parameters in the rats}

The contents of total cholesterol (TC), high-density lipoprotein-cholesterol (HDL-C), low-density lipoproteincholesterol (LDL-C), and triglyceride (TG) in serum were measured by Automatic Chemistry Analyzer (Hitachi, Tokyo, Japan). TC, TG and free cholesterol (FC) contents in liver were determined using enzymatic assay kits, including Tissue total cholesterol assay kit E1015, Tissue free cholesterol assay kit E1016 and Tissue triglyceride assay kit E1003-2, respectively, from Applygen Technologies Inc. (Beijing, China). Fecal bile acid content was measured according to the rats bile acids ELISA kit from Sen Shellfish Gamma Biotechnology Limited Company (NanJing Nanjing, China), and fecal cholesterol was measured using Tissue total cholesterol assay kit E1015. The fecal total lipid was determined by Soxhlet method.

\section{Statistical analysis}

Data were expressed as means \pm standard error of mean $(n=7)$ in rat study. Statistical analysis was performed by one-factorial analysis of variance (ANOVA) test. Significant differences $(P<0.05)$ were analyzed by Tukey-Kramer's $\mathrm{t}$ test for post-hoc multiple comparisons. 
Table 5 Tochopherol contents in different oat groups and soybean oil (mg/kg oil)

\begin{tabular}{|c|c|c|c|c|c|}
\hline & a-Tocopherol & $\beta$-Tocopherol & $\mathrm{Y}$-Tocopherol & $\delta$-Tocopherol & ${ }^{1}$ Total vitamin $\mathrm{E}$ \\
\hline Jinyan-No.13 & 88.3 & 76.5 & 203.9 & 108.8 & 442.3 \\
\hline Bayou-No.8 & 90.8 & - & 258.3 & 128.3 & 463.5 \\
\hline Baiyan-No.2 & 83.4 & 60.0 & 194.5 & 136.1 & 447.2 \\
\hline Dingyou-No.8 & 114.7 & - & 197.4 & 124.9 & 471.9 \\
\hline Baiyan-No.8 & 82.6 & 93.5 & 196.8 & 136.0 & 450.2 \\
\hline Control & 28.9 & 365.6 & 14.8 & 19.7 & 407.3 \\
\hline
\end{tabular}

${ }^{1}$ The data of Total Vitamin E was the sum of $a$-Tocopherol, $\beta$-Tocopherol, $\gamma$-Tocopherol and $\delta$-Tocopherol.

- unidentified.

\section{Results}

Figure 1 showed $\beta$-glucan, lipid and protein contents of twenty-eight oat varieties. The content of $\beta$-glucan ranged from $3.01 \% \sim 6.54 \%$, and its average was $4.76 \%$; the content of protein ranged from $14.66 \% \sim 19.99 \%$, and its average was $17.44 \%$; the content of lipid ranged from $4.02 \% \sim 7.94 \%$, and its average was $5.95 \%$. Five oat varieties, Jinyan-No.13, Bayou-No.8, Baiyan-No.2, DingyouNo.8 and Baiyan-No.8, were selected based on Figure 1, which contained similar $\beta$-glucan content and gradient content of protein and lipid. The compositions of five oat varieties were shown in Table 2 . The amino acid compositions of casein and oat proteins were shown in Table 3. As shown in Table 3, the ratio of lysine/arginin in oat proteins ranged from $0.59 \sim 0.66$ and the ratio of methionin/glycine ranged from $0.27 \sim 0.35$, both of which were lower in oat groups than those in control group. Table 4 showed the fatty acid compositions of the soybean oil and oats lipids, and indicated that the concentration of unsaturated fatty acids was higher in control group than that in oat groups. The tocopherol contents in different groups of oat and soybean oil were shown in Table 5. With the contents of total Vitamin $\mathrm{E}$ among five oat groups were almost the same, the total vitamin $\mathrm{E}$ contents in oat groups were higher than that in soybean oil. Table 6 showed the major plant sterol components of oats and soybean oil, which indicated the concentrations of total

Table 6 Major sterol contents in different oat groups and soybean oil (mg/ kg oil)

\begin{tabular}{lcccc}
\hline & Campesterol & Stigmasterol & $\boldsymbol{\beta}$-Sitosterol & $\begin{array}{c}\text { 1 Total } \\
\text { sterols }\end{array}$ \\
\hline Jinyan-No.13 & 243.3 & 183.7 & 337.6 & 764.6 \\
Bayou-No.8 & 275.8 & 180.7 & 313.6 & 770.1 \\
Baiyan-No.2 & 398.1 & 85.9 & 297.4 & 781.3 \\
Dingyou-No.8 & 330.3 & 52.2 & 377.7 & 760.2 \\
Baiyan-No.8 & 344.7 & 88.2 & 355.9 & 788.8 \\
Control & 84.2 & 276.3 & 322.2 & 682.7 \\
\hline
\end{tabular}

${ }^{1}$ The data of total sterols was the sum of campesterol, stigmastrol, and $\beta$-sitosterol. sterols in oats were basically consistent, but higher than that in soybean oil.

The initial body weight, final body weight, body weight gain and food intake for all groups were shown in Table 7. There were no significant differences in any parameters among six groups fed experimental diets for 30 days.

Table 7 also showed the serum, liver and fecal lipids profiles of rats after treating with experimental diets for 30 days. Dietary Baiyan-No.2, Dingyou-No.8, and BaiyanNo.8 significantly reduced both serum TC and LDL-C levels compared with control group, while dietary JinyanNo.13 and Bayou-No.8 only decreased serum TC levels significantly. Serum HDL-C and TG concentrations of five oat groups were not significantly different from that of control group. The concentrations of liver TC and CE in oat groups were significantly reduced compared with control group. Besides Baiyan-No.2 group, the contents of liver FC were also significantly decreased in other four oat groups. Liver TG contents and fecal lipids excretion were not changed. In addition, fecal bile acid excretion was increased in oat groups, while the fecal cholesterol excretion was decreased. Fecal weight was increased in DingyouNo.8 group, but not in other four oat groups.

Comparison between oat proteins/oat lipids and the percentage reduction of serum total cholesterol and LDL-cholesterol were shown in Figure 2 and Figure 3. The percentage reduction of total cholesterol and LDLcholesterol were higher after rats obtained higher contents of oat proteins. The similar tendency was also found between oat lipids and the percentage reduction of serum total cholesterol and LDL-cholesterol. It was indicated that the percentage reduction of serum total cholesterol and LDL-cholesterol depended on the contents of proteins and lipids, and the impact from high to low in order was: Baiyan-No.8, Dingyou-No.8, BaiyanNo.2, Bayou-No.8, and Jinyan-No.13.

\section{Discussion}

It has been demonstrated that intake of oat products or oat bran could decrease cholesterol levels of serum in human and animals $[21,22]$. In the present study, we chose 
Table 7 Growth parameters and lipid indexes in serum, liver and feces of rats fed the experimental diets for 30 days

\begin{tabular}{|c|c|c|c|c|c|c|}
\hline & Control & Jinyan-No.13 & Bayou-No.8 & Baiyan-No.2 & Dingyou-No.8 & Baiyan-No.8 \\
\hline \multicolumn{7}{|l|}{ Growth Parameters } \\
\hline Initial BW (g) & $270.3 \pm 4.1$ & $267.4 \pm 6.4$ & $268.7 \pm 4.1$ & $282.0 \pm 6.7$ & $277.0 \pm 7.3$ & $263.4 \pm 5.9$ \\
\hline Final BW (g) & $353.3 \pm 11.4$ & $341.9 \pm 4.6$ & $338.1 \pm 9.2$ & $355.7 \pm 8.0$ & $353.6 \pm 9.7$ & $357.0 \pm 6.3$ \\
\hline BW gain (g) & $134.0 \pm 8.8$ & $129.1 \pm 4.0$ & $128.9 \pm 6.7$ & $132.3 \pm 3.1$ & $129.0 \pm 4.7$ & $143.6 \pm 7.5$ \\
\hline Food intake (g/day) & $22.6 \pm 0.5$ & $22.2 \pm 0.5$ & $22.5 \pm 0.3$ & $22.2 \pm 0.2$ & $22.3 \pm 0.5$ & $21.4 \pm 0.3$ \\
\hline \multicolumn{7}{|l|}{ Serum (mmol/L) } \\
\hline $\mathrm{TC}$ & $2.12 \pm 0.13^{\mathrm{a}}$ & $1.88 \pm 0.10^{b}$ & $1.71 \pm 0.12^{c}$ & $1.56 \pm 0.09^{c d}$ & $1.54 \pm 0.06^{\mathrm{cd}}$ & $1.47 \pm 0.09^{d}$ \\
\hline TG & $0.71 \pm 0.16$ & $0.72 \pm 0.17$ & $0.80 \pm 0.14$ & $0.58 \pm 0.10$ & $0.54 \pm 0.07$ & $0.55 \pm 0.08$ \\
\hline $\mathrm{HDL}-\mathrm{C}$ & $1.35 \pm 0.07$ & $1.32 \pm 0.06$ & $1.31 \pm 0.06$ & $1.35 \pm 0.08$ & $1.29 \pm 0.05$ & $1.24 \pm 0.05$ \\
\hline LDL-C & $0.46 \pm 0.05^{a}$ & $0.46 \pm 0.04^{a}$ & $0.36 \pm 0.05^{\mathrm{ab}}$ & $0.34 \pm 0.03^{b}$ & $0.35 \pm 0.02^{b}$ & $0.32 \pm 0.02^{b}$ \\
\hline \multicolumn{7}{|l|}{ Liver ( $\mu \mathrm{mol} / \mathrm{g}$ ) } \\
\hline $\mathrm{TC}$ & $81.03 \pm 2.64^{a}$ & $63.04 \pm 1.27^{c}$ & $63.01 \pm 1.56^{c}$ & $72.27 \pm 2.38^{b}$ & $51.77 \pm 2.46^{d}$ & $47.72 \pm 1.76^{d}$ \\
\hline CE & $75.04 \pm 2.67^{\mathrm{a}}$ & $61.22 \pm 1.20^{\mathrm{b}}$ & $61.21 \pm 1.54^{\mathrm{b}}$ & $62.35 \pm 3.02^{b}$ & $50.23 \pm 2.56^{c}$ & $44.94 \pm 1.45^{c}$ \\
\hline $\mathrm{FC}$ & $5.99 \pm 0.66^{b}$ & $1.82 \pm 0.34^{c}$ & $1.80 \pm 0.35^{c}$ & $9.92 \pm 1.83^{\mathrm{a}}$ & $1.54 \pm 0.41^{c}$ & $2.78 \pm 0.52^{c}$ \\
\hline TG & $93.74 \pm 7.49$ & $85.38 \pm 8.54$ & $100.36 \pm 9.23$ & $103.41 \pm 7.57$ & $105.81 \pm 14.39$ & $107.24 \pm 8.53$ \\
\hline \multicolumn{7}{|l|}{ Feces } \\
\hline Feces weight $(\mathrm{g} / \mathrm{d})$ & $1.96 \pm 0.03^{\mathrm{a}}$ & $2.13 \pm 0.03^{\mathrm{a}}$ & $2.07 \pm 0.03^{a}$ & $2.07 \pm 0.04^{\mathrm{a}}$ & $2.40 \pm 0.05^{b}$ & $2.04 \pm 0.04^{\mathrm{a}}$ \\
\hline Total fat (g/d) & $0.148 \pm 0.007$ & $0.150 \pm 0.006$ & $0.159 \pm 0.005$ & $0.148 \pm 0.005$ & $0.152 \pm 0.006$ & $0.136 \pm 0.005$ \\
\hline $\mathrm{TC}(\mu \mathrm{mol} / \mathrm{d})$ & $66.3 \pm 5.9^{a}$ & $49.3 \pm 3.4^{b}$ & $54.6 \pm 5.1^{b}$ & $52.7 \pm 3.6^{b}$ & $45.8 \pm 3.6^{c}$ & $43.4 \pm 3.5^{c}$ \\
\hline Bile acid $(\mu \mathrm{mol} / \mathrm{d})$ & $47.5 \pm 2.14^{\mathrm{a}}$ & $54.7 \pm 2.31^{b}$ & $50.5 \pm 2.01^{a}$ & $56.1 \pm 2.41^{b}$ & $61.3 \pm 4.10^{b}$ & $53.7 \pm 1.98^{b}$ \\
\hline
\end{tabular}

Data are means $\pm \mathrm{SE}(n=7)$. Values not sharing a common letter are significantly different at $P<0.05$, by Tukey-Kramer multiple comparisons. $B W$, body weight; $T G$, triacylglycerol; $C H O L$, cholesterol; HDL-C, HDL-cholesterol; LDL-C, LDL-cholesterol.

five oat varieties with different contents of proteins and lipids, but similar content of $\beta$-glucan, to investigate the cholesterol-lowing effects of oat components in rats. As the results, all tested oat varieties played the cholesterollowering effects, but the hypocholesterolemic degree among different oat groups was significantly different (Table 7). This result indicated that other components in oat were responsible for the observed effects. Moreover, the ability of different oat varieties to reduce serum total cholesterol and LDL-cholesterol concentrations increased with the increase of the proteins and lipids contents, but had nothing to do with starch contents (Figure 2 and Figure 3). These findings suggest that the proteins and lipids in oats may play the cholesterol-lowering effects.

In fact, numerous studies have demonstrated the cholesterol-lowering effect of plant proteins in soybean $[12]$, rice $[14,15]$ and buckwheat $[23,24]$ in animals fed cholesterol enriched diet. Moreover, Rajamohan et al. discovered that sesame protein showed stronger reduction of serum cholesterol level than casein, probably due to its low ratio of lysine/arginine (0.67) [25]. Similarly, Morita et al. found that cholesterol-lowering effects of soybean protein depended on its low ratio of methionine/glycine (0.323) into rats fed a cholesterol-free purified diet [12]. In the present study, the ratio of lysine/arginine and methionine/glycine of oats proteins were lower than that of casein, but similar to sesame proteins and soybean proteins (Table 3). These findings could account for the cholesterol-lowering effect of oat was closely related to its protein contents, namely, the higher contents of oat proteins, the lower total cholesterol and LDLcholesterol levels of serum were observed in rats fed a hypocholesterolemic diet.

Rice bran oil and its consumption have been reported to decrease cholesterol levels of serum significantly in human and animal $[26,27]$. Richard et al. concluded that oat bran affected cholesterol metabolism through lipids and non-starch polysaccharides in adult male rats fed a cholesterol-free synthetic diet [28]. The present study showed that the higher contents of oat lipids led to the lower total cholesterol and LDL-cholesterol levels of serum in rats. Besides oat proteins, lipids were also involved in the cholesterol-lowering effect of oat. Furthermore, it was reported that dietary monounsaturated fatty acid and polyunsaturated fatty acid diets resulted in lower serum total cholesterol and low-density-lipoprotein cholesterol in human [29]. Our study found that the rats fed hypercholesterolemic diets supplemented with oats ingested less amount 

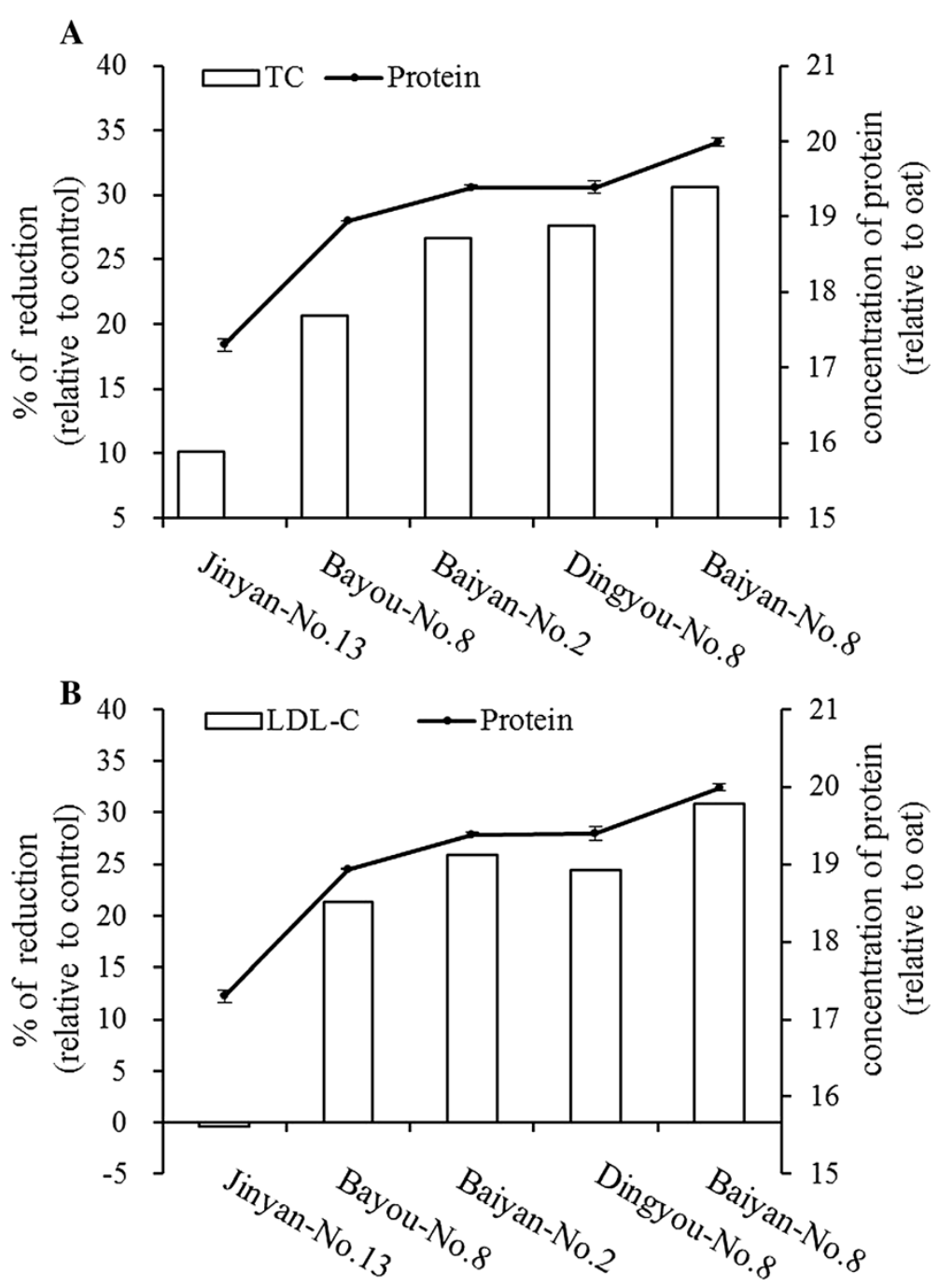

Figure 2 Comparison between the contents of oat proteins and the percentage reduction of serum TC (A) and LDL-C (B) in rats fed experiment diets. The contents of oat proteins are expressed as mean $\pm S D(n=3)$. TC, total cholesterol; LDL-C, LDL-cholesterol.

of unsaturated fatty acids than control group (Table 4), suggesting that the hypolipidemic effect of oat lipids was not simply dependent on its fatty acid composition.

Previous studies reported that supplementation with vitamin $\mathrm{E}$ could reduce plasma levels of LDL and oxidized LDL [30], meanwhile inhibit oxidation of LDL cholesterol and prevent atherosclerosis [31]. The most abundant phytosterol of oat were campesterol, stigmastrol, and $\beta$-sitosterol [32]. Numerous studies reported that plant sterols had cholesterol-lowering effect by inhibiting the absorption of intestinal cholesterol [33]. Plant sterols could displace cholesterol from bile salt micelles and restrict the micellar solubility of cholesterol, which accounted for the inhibitory effect on cholesterol absorption [33-35]. Our results showed that the concentrations of total vitamin $\mathrm{E}$ and total plant sterols among five oat groups were similar, but they were higher than that in the control group (Table 5 and Table 6). Together with the really low contents of vitamin $\mathrm{E}$ and plant sterols in the hypercholesterolemic diets in the present study, it was impossible to illustrate which of these two components was responsible for the hypolipidemic effects alone.

Numerous studies demonstrated that dietary red palm oil supplementation offered significant protection against ischemia/reperfusion-induced injury in the isolated perfused rat heart by improving functional recovery [36-38]. The oleic, linoleic, tocopherol and tocotrienol, sterols, squalene, and CoQ10 were considered to be the main functional components [36,39]. It has been reported that pretreatment with a combination of vitamins A and E showed protection against venous ischemia/reperfusioninduced injury, but these vitamins were not effective 


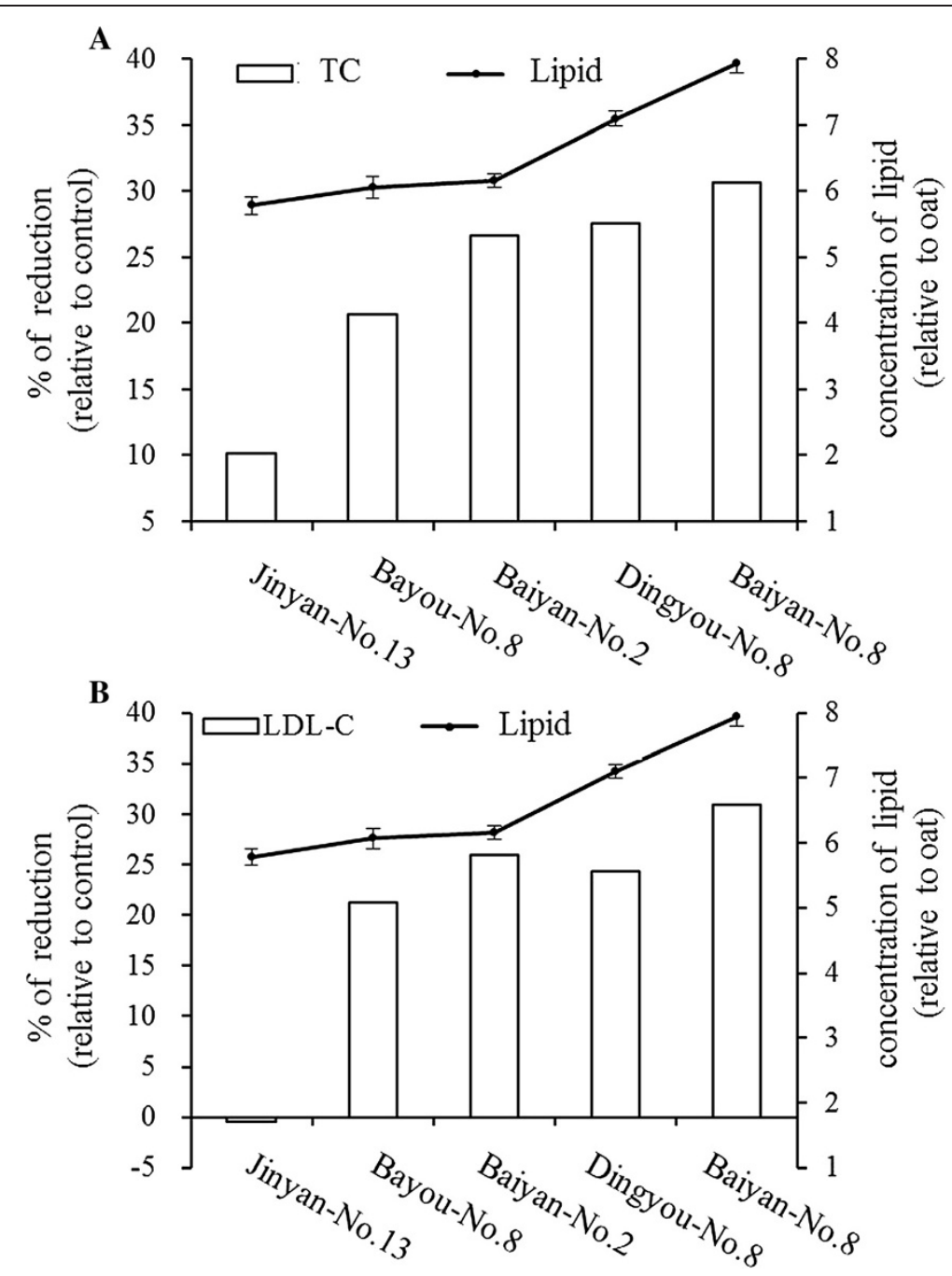

Figure 3 Comparison between the contents of oat lipids and the percentage reduction of serum TC (A) and LDL-C (B) in rats fed experiment diets. The contents of oat lipids are expressed as mean $\pm S D(n=3)$. TC, total cholesterol; $L D L-C$, LDL-cholesterol.

when they were used as single agents [40]. Therefore, we speculate that the hypocholesterolemic properties of oat lipids could not be attributed to one single component, but to the combination of oleic acid, vitamin E, or plant sterols.

Inhibition of lipids absorption in small intestines and increase of excretion of fecal bile acids in the liver were thought to be the hypocholesterolemic mechanisms of oat $[41,42]$. In this study, dietary oats resulted in the significant decrease of TC and CE concentrations in liver, and oat groups increased daily excretion of bile acids, but did not promote the excretion of fecal cholesterol. It indicated that diet oats decreased serum and liver cholesterol concentrations by promoting the excretion of fecal bile acids.

It has been reported that intake of fish oil and fish proteins showed different ways to regulate cholesterol levels in serum and liver. Dietary fish proteins decreased serum and liver cholesterol through increasing fecal cholesterol, bile acids excretion and liver cholesterol $7 \alpha$-hydroxylase expression level, while dietary fish oil decreased liver cholesterol perhaps due to the suppression of cholesterol synthesis through a decrease in the 3-hydroxy-3methylglutaryl-coenzyme A reductase expression level . In our study, the concentrations of liver cholesterols and/or fecal bile acids were not affected by proteins and lipids, which may be due to different ways of $\beta$-glucan, proteins and lipids to regulate cholesterol levels. However, the exact mechanisms of cholesterollowering effects of $\beta$-glucan, proteins and lipids in oat still need further researches.

\section{Conclusions}

The present study showed that dietary oats decreased the concentrations of plasma and liver cholesterol in 
Wistar-Lewis rats fed with a hypercholesterolemic diet by increasing daily excretions of fecal bile acids. Dietary oats improved hypercholesterolemia, not only attribute to $\beta$-glucan but also related to the proteins and lipids. Furthermore, the cholesterol-lowering effect of proteins in oats could be attributed to its more reasonable lysine/ arginin and methionin/glycine ratio and the hypocholesterolemic properties of oat lipids due to the combination of oleic acid, linoleic, vitamin E, or plant sterols.

\section{Competing interests}

The authors declare that they have no competing interests.

\section{Authors' contributions}

LG, Conception and design, Analysis and interpretation, Data Collection, Writing the article, Critical revision of the article, Statistical analysis and Overall Responsibility. L-TT, Conception and design, Analysis and interpretation, Data Collection, Writing the article, Critical revision of the article, Statistical analysis and Overall Responsibility. LL, Analysis and interpretation, Data Collection and Overall Responsibility. KZ, Analysis and interpretation, Data Collection and Overall Responsibility. JQ, Analysis and interpretation, Data Collection, Writing the article, and Overall Responsibility. SZ, Conception and design, Analysis and interpretation, Data Collection, Writing the article, Critical revision of the article, Final approval of the article, Statistical analysis and Overall Responsibility. All authors read and approved the final manuscript.

\section{Acknowledgments}

This work was supported by the National Natural Science Foundation of China (Grant No. 31071516).

\section{Author details}

${ }^{1}$ Institute of Agro-Products Processing Science and Technology, Chinese Academy of Agricultural Sciences/Key Laboratory of Agro-Products Processing, Ministry of Agriculture, 100193 Beijing, China. Institute of Food and Nutrition Development, Ministry of Agriculture, 12 Zhongguancun South Street, Haidian District, 100081 Beijing, China.

Received: 31 July 2014 Accepted: 29 November 2014

Published: 5 December 2014

\section{References}

1. Chen J, He J, Wildman RP, Reynolds K, Streiffer RH, Whelton PK: A randomized controlled trial of dietary fiber intake on serum lipids. Eur J Clin Nutr 2006, 60:62-68.

2. Zdunczyk Z, Flis M, Zielinski H, Wróblewska M, Antoszkiewicz Z, Juskiewicz J In vitro antioxidant activities of barley, husked oat, naked oat, triticale, and buckwheat wastes and their influence on the growth and biomarkers of antioxidant status in rats. J Agric Food Chem 2006, 54:4168-4175.

3. Berg A, König D, Deibert P, Grathwohl D, Baumstark M, Franz IW: Effect of an oat bran enriched diet on the atherogenic lipid profile in patients with an increased coronary heart disease risk. Ann Nutr Metab 2003, 47:306-311.

4. Tapola N, Karvonen H, Niskanen L, Mikola M, Sarkkinen E: Glycemic responses of oat bran products in type 2 diabetic patients. Nutr Metab Cardiovas 2005, 15:255-261.

5. Brindzova L, Certik M, Rapta P, Zalibera M, Mikulajova A, Takacsova M: Antioxidant activity, $\beta$-glucan and lipid contents of oat varieties. Czech J Food Sci 2008, 26:163-173.

6. Queenan KM, Stewart ML, Smith KN, Thomas W, Fulcher RG, Slavin JL: Concentrated oat $\beta$-glucan, a fermentable fiber, lowers serum cholesterol in hypercholesterolemic adults in a randomized controlled trial. Nutr J 2007, 6:6.

7. Ryan D, Kendall M, Robards K: Bioactivity of oats as it relates to cardiovascular disease. Nutr Res Rev 2007, 20:147-162.

8. Andersson AA, Börjesdotter D: Effects of environment and variety on content and molecular weight of $\beta$-glucan in oats. J Cereal Sci 2011, 54:122-128.
9. Mirmoghtadaie L, Kadivar M, Shahedi M: Effects of succinylation and deamidation on functional properties of oat protein isolate. Food Chem 2009, 114:127-131.

10. Aro H, Järvenpää E, Könkö K, Huopalahti R, Hietaniemi V: The characterisation of oat lipids produced by supercritical fluid technologies. J Cereal Sci 2007, 45:116-119.

11. Hoover R, Smith C, Zhou Y, Ratnayake R: Physicochemical properties of Canadian oat starches. Carbohyd Polym 2003, 52:253-261.

12. Sugano M, Yamada Y, Yoshida K, Hashimoto Y, Matsuo T, Kimoto M: The hypocholesterolemic action of the undigested fraction of soybean protein in rats. Atherosclerosis 1988, 72:115-122.

13. Sugano M, Goto S, Yamada Y, Yoshida K, Hashimoto Y, Matsuo T, Kimoto M: Cholesterol-lowering activity of various undigested fractions of soybean protein in rats. J Nutr 1990, 120:977-985.

14. Morita T, Oh-hashi A, Kasaoka S, Ikai M, Kiriyama S: Rice protein isolates produced by the two different methods lower serum cholesterol concentration in rats compared with casein. J Sci Food Agr 1996, 71:415-424

15. Ni W, Tsuda Y, Takashima S, Sato H, Sato M, Imaizumi K: Anti-atherogenic effect of soya and rice-protein isolate, compared with casein, in apolipoprotein E-deficient mice. Brit J Nutr 2003, 90:13-20.

16. Kayashita J, Shimaoka I, Nakajoh M, Yamazaki M, Kato N: Consumption of buckwheat protein lowers plasma cholesterol and raises fecal neutral sterols in cholesterol-fed rats because of its low digestibility. J Nutr 1997, 127:1395-1400.

17. Zhou M, Robards K, Glennie-Holmes M, Helliwell S: Oat lipids. J Am Oil Chem Soc 1999, 76:159-169.

18. Molteberg EL, Vogt G, Nilsson A, Frolich W: Effects of storage and heat processing on the content and composition of free fatty acids in oats. Cereal Chem 1995, 72:88-93.

19. Piironen V, Toivo J, Lampi AM: Plant sterols in cereals and cereal products. Cereal Chem 2002, 79:148-154.

20. Judd $P$, Truswell A: The effect of rolled oats on blood lipids and fecal steroid excretion in man. Am J Clin Nutr 1981, 34:2061-2067.

21. Anderson JW, Jones AE, Riddell-Mason S: Ten different dietary fibers have significantly different effects on serum and liver lipids of cholesterol-fed rats. J Nutr 1994, 124:78-83.

22. Naumann E, VaN Rees AB, Önning G, Öste R, Wydra M, Mensink RP: $\beta$-Glucan incorporated into a fruit drink effectively lowers serum LDL-cholesterol concentrations. Am J Clin Nutr 2006, 83:601-605.

23. Tomotake H, Shimaoka I, Kayashita J, Yokoyama F, Nakajoh M, Kato N: A buckwheat protein product suppresses gallstone formation and plasma cholesterol more strongly than soy protein isolate in hamsters. J Nutr 2000, 130:1670-1674.

24. Tovar AR, Torre-Villalvazo I, Ochoa M, Elías AL, Ortíz V, Aguilar-Salinas CA, Torres N: Soy protein reduces hepatic lipotoxicity in hyperinsulinemic obese Zucker fa/fa rats. J Lipid Res 2005, 46:1823-1832.

25. Rajamohan T, Kurup P: Lysine: arginine ratio of a protein influences cholesterol metabolism Part 1-Studies on sesame protein having low lysine: arginine ratio. Indian J Exp Biol 1997, 35:1218-1223.

26. Most MM, Tulley R, Morales S, Lefevre M: Rice bran oil, not fiber, lowers cholesterol in humans. Am J Clin Nutr 2005, 81:64-68.

27. Sharma R, Rukmini C: Rice bran oil and hypocholesterolemia in rats. Lipids 1986, 21:715-717.

28. Illman RJ, Topping DL, Dowling K, Trimble RP, Russell GR, Storer GB: Effects of solvent extraction on the hypocholesterolaemic action of oat bran in the rat. Br J Nutr 1991, 65:435-443.

29. Behall K, Scholfield D, Hallfrisch J: Effect of beta-glucan level in oat fiber extracts on blood lipids in men and women. J Am Coll Cardiol 1997, 16:46-51.

30. Mune M, Yukawa S, Kishino M, Otani H, Kimura K, Nishikawa O, Takahashi T, Kodama N, Saika Y, Yamada Y: Effect of vitamin E on lipid metabolism and atherosclerosis in ESRD patients. Kidney Int 1999, 56:S126-S129.

31. Suzukawa M, Ayaori M, Shige H, Hisada T, Ishikawa T, Nakamura H: Effect of supplementation with vitamin E on LDL oxidizability and prevention of atherosclerosis. Biofactors 1998, 7:51-54.

32. Määttä K, Lampi AM, Petterson J, Fogelfors BM, Piironen V, Afaf KE: Phytosterol content in seven oat cultivars grown at three locations in Sweden. J Sci Food Agric 1999, 79:1021-1027.

33. Ikeda I, Tanaka K, Sugano M, Vahouny G, Gallo L: Inhibition of cholesterol absorption in rats by plant sterols. J Lipid Res 1988, 29:1573-1582. 
34. Heinemann T, Kullak-Ublick GA, Pietruck B, Von-Bergmann K: Mechanisms of action of plant sterols on inhibition of cholesterol absorption. Eur J Clin Pharmacol 1991, 40:S59-S63.

35. Wester I: Cholesterol-lowering effect of plant sterols. Eur J Lipid Sci Tech 2000, 102:37-44.

36. Engelbrecht AM, Esterhuyse J, Toitc EF, Lochnerc A, Rooyena JV: p38-MAPK and PKB/Akt, possible role players in red palm oil-induced protection of the isolated perfused rat heart. J Nutr Biochem 2006, 17:265-271.

37. Bester1 DJ, Kupai K, Csont T, Szucs G, Csonka C, Esterhuyse AJ, Ferdinandy P, Rooyen JV: Dietary red palm oil supplementation reduces myocardial infarct size in an isolated perfused rat heart model. Lipids in Health and Dis 2010, 9:64

38. Szucs G, Bester DJ, Kupai K, Csont T, Csonka C, Esterhuyse AJ, Ferdinandy P, Rooyen JV: Dietary red palm oil supplementation decreases infarct size in cholesterol fed rats. Lipids Health Dis 2011, 10:103.

39. Ródenas S, Rodríguez-Gil S, Merinero MC, Sánchez-Muniz FJ: Dietary exchange of an olive oil and sunflower oil blend for extra virgin olive oil decreases the estimate cardiovascular risk and LDL and apolipoprotein All concentrations in postmenopausal women. J Am Coll Nutr 2005, 5:361-369.

40. Bilgin-Karabulut A, Ademoglu E, Aydin I, Erer M, Gokkusu C: Protective effects of vitamins $A$ and $E$ pretreatment in venous ischemia/reperfusion injury. J Reconstr Microsurg 2001, 17:425-429.

41. Lia A, Hallmans G, Sandberg AS, Sundberg B, Aman P, Andersson H: Oat beta-glucan increases bile acid excretion and a fiber-rich barley fraction increases cholesterol excretion in ileostomy subjects. Am J Clin Nutr 1995, 62:1245-1251.

42. Marlett JA, Hosig KB, Vollendorf NW, Shinnick FL, Haack VS, Story JA: Mechanism of serum cholesterol reduction by oat bran. Hepatology 1994 , 20:1450-1457.

doi:10.1186/1476-511X-13-182

Cite this article as: Guo et al:: The cholesterol-lowering effects of oat varieties based on their difference in the composition of proteins and lipids. Lipids in Health and Disease 2014 13:182.

\section{Submit your next manuscript to BioMed Central and take full advantage of:}

- Convenient online submission

- Thorough peer review

- No space constraints or color figure charges

- Immediate publication on acceptance

- Inclusion in PubMed, CAS, Scopus and Google Scholar

- Research which is freely available for redistribution 